Pesq. Vet. Bras. 36(9):837-843, setembro 2016 DOI: 10.1590/S0100-736X2016000900008

\title{
Major health problems and their economic impact on beef cattle under two different feedlot systems in Brazil ${ }^{1}$
}

\author{
Pedro Malafaia ${ }^{2 *}$, Tiago Alvin Lima Granato ${ }^{3}$, Rogério Magnoli Costa ${ }^{4}$, Vinícius \\ Carneiro de Souza ${ }^{5}$, Diogo Fleury Azevedo $\operatorname{Costa}^{6}$ and Carlos Hubinger Tokarnia ${ }^{2+}$
}

\begin{abstract}
Malafaia P., Granato T.A.L., Costa R.M., Souza V.C., Costa D.F.A. \& Tokarnia C.H. 2016. Major health problems and their economic impact on beef cattle under two different feedlot systems in Brazil. Pesquisa Veterinária Brasileira 36(9):837-843. Departamento de Nutrição Animal e Pastagem, Instituto de Zootecnia, Universidade Federal Rural do Rio de Janeiro, Seropédica, RJ 23890-000, Brazil. E-mail: malafaia_ufrrj@yahoo.com.br

This study aimed to describe the diagnosis of health problems and to evaluate the cost of their treatment for cattle raised in feedlots to be slaughtered or to be sold as sires for cow-calf systems. Bovine respiratory disease and digestive disorders were the main problems diagnosed in the feedlot for slaughter; the cost for treatment was high, accounting for 9.7 to $20.9 \mathrm{~kg}$ of live weight (LW) or the equivalent of 7 to $15 \%$ of total LW gained over the days on feed. Due to the high intake of starch-rich concentrate, rumen and fecal $\mathrm{pH}$ was lower, whilst rumen osmolarity and blood lactate were higher in cattle fed for slaughter. Cattle affected by digestive disorders spent on average four additional days in the feedlot. Diseases and cost of treatments were associated with lower average daily gain and considerable economic losses. Health problems commonly observed in the feedlots for slaughter were not observed in the feedlots for males to be sold as sires. The most likely reason for this observation was the more careful nutrition and prophylactic health management in sire production systems, which produce animals of much higher selling price. Results from this study suggest that health problems found in feedlots for slaughter may not only reduce animal productivity and profitability, but also the welfare of the animals. The systemic understaffing of livestock cattle workers and veterinarians in large feedlots in Brazil results in under reporting of diseases and lack to understand epidemiological context and disease prevention.
\end{abstract}

INDEX TERMS: Beef cattle, feedlot systems, Brazil, diseases of cattle, sires.

RESUMO.- [Principais problemas sanitários e seu impacto econômico em bovinos de corte criados em diferentes tipos de confinamento no Brasil.] No presente estudo coletou-se e se interpretou dados sobre os principais problemas sanitários, bem como a respeito dos cus-

\footnotetext{
${ }^{1}$ Received on June 30, 2016.

Accepted for publication on July 12, 2016.

${ }^{2}$ Departamento de Nutrição Animal e Pastagem, Universidade Federal Rural do Rio de Janeiro (UFRRJ, Seropédica, RJ 23851-970, Brazil. * Corresponding author: malafaia_ufrrj@yahoo.com.br

${ }^{3}$ Biotec Reprodução Animal e Consultoria Pecuária, Av. Tancredo Neves Q37, L13, Nova Crixás, G0 76520-000, Brazil.

${ }^{4}$ Exito Rural Consultoria em Pecuária, Av. Mario Covas 2747, Araçatuba, SP16025-100, Brazil.

${ }^{5}$ Departamento de Zootecnia, Universidade Estadual Paulista (Unesp), Rodovia Prof. Paulo Donato Castellane Km 5, Jaboticabal, SP 14884-900, Brazil.

${ }^{6}$ Centro Universitário de Octavio Bastos, Av. Dr. Octávio Bastos 2439, São João da Boa Vista, SP 13874-149, Brazil.
}

tos com os tratamentos de bovinos de corte confinados em dois sistemas diferentes: o tradicional, isto é, aquele que objetiva produzir animais prontos para o abate e o sistema de produção de touros destinados à venda destes como reprodutores. A porcentagem de bovinos confinados para o abate e que adquiriram problemas sanitários foi consideravelmente maior do que nos sistemas que os confinam para a venda como futuros reprodutores. As pneumonias e os transtornos digestórios foram os principais problemas diagnosticados no confinamento para o abate e os custos com os tratamentos foram elevados e, em média, representaram entre 9,7 e $20,9 \mathrm{~kg}$ de peso vivo ou o equivalente de 7 a $15 \%$ das arrobas ganhas durante o período confinado. 0 crescimento exagerado e a aglutinação (paraqueratose) das papilas ruminais foram os principais achados macroscópicos nos rúmens dos bovinos confinados para o abate. Devido à maior ingestão de grãos, o pH ruminal e fecal foi sempre menor, enquanto que a osmolaridade ruminal e o 
lactato sanguíneo foi sempre maior nos animais confinados para o abate. 0 tempo de permanência no confinamento foi maior, em média 4 dias, para os animais que adquiriram qualquer problema digestório. Isso, aliado ao fato de também terem os menores ganhos de peso diários, pode resultar em um considerável prejuízo. Os ganhos de peso diários foram similares para os animais confinados (que ingeriram mais de $85 \%$ de concentrados) para o abate e para os que foram confinados para a venda como reprodutores, que consumiram cerca de $50 \%$ de concentrados em sua dieta.

TERMOS DE INDEXAÇÃO: Bovinos de corte, confinamentos, Brasil, doenças de bovinos, touros.

\section{INTRODUCTION}

Raising cattle in feedlots is an important alternative for beef production, in particular for the provision of high quality meat for more demanding markets. In Brazil, finishing cattle in feedlots became more significant from the 1980s. In 2014, about $2.35 \%$ of the Brazilian beef cattle herd (198.7 million head) were finished in feedlots, what is equivalent to $10.8 \%$ of the 43.3 million head officially slaughtered nationwide (Anualpec 2014).

In addition to economic and market challenges, there is considerable health issues associated with feedlot cattle. After respiratory diseases, nutritional disorders are the second cause of losses in American beef cattle feedlots (Nagaraja \& Lechtenberg 2007). Among these, ruminal acidosis is the most common condition caused by high intake of grains rich in starch and low consumption of physically effective fiber (Malafaia et al. 2011).

In Brazil, little is known about the incidence and prevalence of respiratory diseases, ruminal acidosis and their impact on health, production and costs in feedlot cattle. In the country, cattle are raised in feedlots for two purposes: (1) rapid fattening before slaughter or (2) to allow faster growth of males to be sold as sires for cow-calf systems. The finishing feedlot is called traditional, and the second one is known as sire production system. This study aimed to describe the diagnosis of the main health problems and to evaluate the cost for their treatment, with the interpretation of rumen, blood and fecal parameters for cattle raised in both systems.

\section{MATERIALS AND METHODS}

Finishing feedlot (traditional system). Data were collected in 2012 and 2013 from a feedlot located in the state of Goiás, which bought and finished about 80,000 head per year. The feedlot finished straight and crossbred Nellore cattle. The diets were composed by 80 to $85 \%$ grains and by-products, and by 15 to $20 \%$ of mombaça (Panicum maximum cv. Mombaça) as roughage on a dry matter (DM) basis. The feeding period varied from 90 to 110 days. Two adaptation diets $\left(\mathrm{A}_{1}\right.$ and $\left.\mathrm{A}_{2}\right)$ with decreasing amounts of roughage were used and fed for one week each. At the end of the second week $\left(\mathrm{A}_{2}\right.$ phase), the cattle were fed a finishing diet $(\mathrm{F})$ with 80 to $85 \%$ concentrate until their slaughter. The concentrate consisted mainly of flaked corn or sorghum, soybean meal, whole cottonseed, molasses, lime, urea, mineral mix and monensin. The proportion of these ingredients in the concentrate varied with their availability and prices over the year. The total ration was fed daily at 8:00, 10:00, 12:00, 14:00, 16:00 and 20:00 hours.

The cattle were kept in open-dirt pens, each containing 230 to 250 animals $\left(10-12 \mathrm{~m}^{2} /\right.$ head). Each pen had a covered bunk area and a water trough. Pens were scraped every 15 to 20 days in order to remove the accumulated feces. Each pen had a sprinkler system installed in the center to assist animals with cooling down to minimize problems related to heat stress and also to decrease dust formation. Cattle were sent for slaughter when they reached 480 to $510 \mathrm{~kg}$ live weight (LW).

Twice daily, four staff members, trained in health care, observed each pen carefully looking for animals showing any sign of health problem (e.g. isolation from rest of the group, atypical posture, diarrhea, bunk avoidance). In such cases, the staff team immobilized the animals and contacted a veterinarian to perform a clinical examination. All information gathered during clinical examination was to achieve a diagnosis with subsequent treatment. In cases of suspected rumen acidosis, the cattle were subjected to specific clinical examination according to Dirksen (1981) recommendationsfor diseases of the digestive system.

After two hours post-feeding, approximately $10 \mathrm{~mL}$ of rumen fluid of ten animals of the $A_{1}, A_{2}$ and $F$ group were collected by rumenocentesis, as described by Kleen et al. (2004), to measure rumen $\mathrm{pH}$ and osmolarity. These parameters were immediately analyzed with a portable $\mathrm{pH}$ meter and an osmometer. Ten samples of feces $(50-100 \mathrm{~g})$ were randomly collected from the floor of the pens from $A_{1}, A_{2}$ and $F$ groups during each phase. Each fecal sample was collected from the top, leaving the part touching the soil behind in order to avoid contamination. The fecal $\mathrm{pH}$ and osmolarity was immediately measured and the samples were then identified, stored in plastic bags and frozen for further analyses.

Blood lactate was evaluated in thirty randomly selected animals from all groups (10 per group) using fresh venous blood collected from the jugular vein. Lactate was measured with test strips for lactate using a portable analyzer.

About 400 to 500 finished cattle were sent for slaughter daily. Two random slaughtering were selected (5/10/2012 and $8 / 5 / 2013)$, in which rumens were randomly collected at the abattoir (about $30 \%$ of total slaughtered animals), and were emptied, washed with water and examined for macroscopic lesions or changes (rumenitis, ulcers, scars, exaggerated papillary growth and coalescence of rumen papillae [parakeratosis]). Any positive cases were recorded and expressed in percentage of all examined rumens. Sixteen fragments of about $5 \mathrm{~cm}^{2}$ of rumen wall at the level of saccus caecus caudodorsalis were sampled from rumens with rumenitis, parakeratosis or with excessive papillae growth. These fragments were immediately immersed into a phosphate buffer solution $\left(0.79 \mathrm{~g} \mathrm{NaCl} ; 0.223 \mathrm{~g} \mathrm{Na}_{2} \mathrm{HPO}_{4} ; 0.0524 \mathrm{~g} \mathrm{NaH}_{2} \mathrm{PO}_{4}\right.$ and $\mathrm{H}_{2} \mathrm{O} 100 \mathrm{~mL}$ ) and cooled down to 3 to $5^{\circ} \mathrm{C}$ to preserve biological characteristics. In the laboratory, each rumen fragment was cut to about $1 \mathrm{~cm}^{2}$ and rumen papillae were sectioned at their base with the use of a scalpel blade. The length and number of papillae per $\mathrm{cm}^{2}$ were evaluated in rumens with rumenitis, parakeratosis or excessive papillae growth. After counting, papillae were placed into a beaker with $20 \mathrm{~mL}$ of distilled water. Subsequently twelve papillae of each type of macroscopic findings were randomly sampled to have their images scanned and areas $\left(\mathrm{mm}^{2} /\right.$ surface area) estimated through Image software (Schneider et al. 2012).

Animals were weighed after fasting, at the beginning of the feedlot period (12 hours water and feed curfew) and again before transportation for slaughter. All carcasses were weighed and carcass yield (CY) calculated after 24 hours cooling. Each animal received a traceability earring on the first day in order to gather information about breed type, diseases, drug administered, initial and final weight. 
Data of diagnosis and any treatments that a specific animal received were easily processed since the feedlot operators used a traceability system. As this feedlot system used only traceable animals for beef export to high quality markets, it was required to inform and describe any diagnosis and treatments used for any disease that a given cattle had during the finishing phase. These data allowed estimation of the costs for disease treatment.

Feedlots to feed males selected as sires. Data were collected on two farms located in Valparaiso/SP (NC Farm) and Guararapes/SP (BA Farm) respectively. The farms raised straight bred Nellore cattle and sell 150 to 180 sires per year. The selection process was based on calf pedigree and their weight at 120 and 210 days (at weaning). After weaning the animals were raised on pasture until they were 480 to $500 \mathrm{~kg}$ LW. Afterwards, they were fed in pens for 120 to 150 days and reach 650 to $680 \mathrm{~kg} \mathrm{LW}$ at which time they were sold as sires.

In these systems, groups containing 30 to 40 cattle were allocated into open-dirt pens $\left(40-45 \mathrm{~m}^{2} /\right.$ head) with a non-covered bunk line and a water trough. The pens were scraped every 15 to 20 days to remove accumulated feces.

The ration was provided twice a day (at 8:00 and16:00 h). The feedlots used 15 to $65 \%$ of concentrate on a DM basis. The concentrate had citrus pulp, soybean hulls, urea, soybean or cottonseed meal. Roughage consisted of either corn or sorghum silage and eventually sugarcane bagasse.

Experimental observations and collections were performed like in the traditional system. However because of the much higher price when sold as sires (an equivalent value of 3.5 to 5.0 times of finished cattle for slaughter), these animals were not rumen biopsied nor was it possible to obtain rumen fluid via ruminocentesis. Each animal was weighed after 12 hours fasting at the beginning and at the end of the feedlot period. Like in the traditional system, a veterinarian diagnosed any condition and provided treatment as required. Using that data, it was possible to estimate the costs for specific disease treatments.

Reference data from animals raised exclusively on pasture. Samples of rumen fluid (obtained by ruminocentesis), feces (taken directly from the rectum) and venous blood were collected from eight adult cattle raised exclusively on Urochloa decumbens or $U$. brizantha pastures. The animals were subjected to a previous clinical examination, and were diagnosed as healthy. The samples were used to provide a reference value for rumen and fecal pH and osmolarity and blood lactate in healthy cattle. Reference samples of rumen fragments of about $5 \mathrm{~cm}^{2}$ of rumen wall at the level of saccus caecus caudodorsalis were sampled from healthy animals after slaughter. These samples were preserved and processed as the ones from the feedlot systems.

Data analysis. For each type of feedlot, diagnoses were established in absolute as well as in relative numbers, i.e. the number of times that a particular case of a disease occurred, divided by the total number of animals exposed to predisposing factors for a particular disease. Performance data were evaluated for homoscedasticity of variances and normality. After meeting these premises, analysis of variance was performed using GLM procedure of SAS (2003). Least square means were estimated and compared using the Tukey test adopting a 5\% level to assess statistical significance. There was no application of hypothesis test for ruminal variables, so all means were described together with a confidence interval of $95 \%$. The estimated $95 \%$ confidence intervals (95\% CI) were presented as follows: $\mu_{x} \pm(U-L) / 2$; Where $\mu$ is the mean of a variable, $\mathrm{x}$; and $U$ and $L$ are the upper and lower limits of the $95 \%$ confidence interval respectively.
Compliance with ethical standards. All procedures were conducted in accordance with the guidelines of the Animal Care and Use Committee of Universidade Federal Rural do Rio de Janeiro, Brazil.

\section{RESULTS}

In the traditional system of feedlots, bovine respiratory disease (BRD) and digestive disorders were the two main health problems, accounting, respectively, for 44.1 to $46.7 \%$ and 31.0 to $32.7 \%$ of all cases diagnosed during the two years of data collection (Table 1). It was not possible to obtain information on the mortality rate of all animals diagnosed with BRD and submitted for treatment.

In the group of animals affected by digestive disorders, rumen acidosis and frothy bloat were the two main problems in finishing cattle during 2012 and 2013 (Table 2).

For two consecutive years, in both feedlots which produced males to be sold as sires, only one animal had to be removed and euthanized due to a traumatic injury.

The costs for treatments of the major health problems in cattle finished for slaughter are shown in Table 3. The

Table 1. Cattle finished for slaughter and number of animals diagnosed and treated for different problems in 2012 and 2013

\begin{tabular}{lcc}
\hline & 2012 & 2013 \\
\hline Total of cattle finished per year & 61126 & 83214 \\
Total of cattle diagnosed and treated & $1942(3.18)$ & $2337(2.81)$ \\
Treated for BRD* & $856(44.1)$ & $1092(46.7)$ \\
Treated for digestive disorders & $636(32.7)$ & $724(31.0)$ \\
Treated for other problems & $450(23.2)$ & $521(22.3)$ \\
$\begin{array}{l}\text { (as abscess, trauma, haematoma, } \\
\text { urolithiasis, skin diseases.) }\end{array}$ & & \\
Cases per day (average) & 5.32 & 6.40 \\
* Bovine respiratory disease. Values in brackets are given as percentages.
\end{tabular}

Table 2. Digestive disorders in cattle finished for slaughter in 2012 and 2013

\begin{tabular}{lcccc}
\hline \multicolumn{1}{c}{ Diagnosis } & 2012 & $\%$ & 2013 & $\%$ \\
\hline Digestive disorders & 636 & $\mathrm{Na}^{*}$ & 724 & $\mathrm{Na}$ \\
Ruminal acidosis & 373 & 58.6 & 429 & 59.3 \\
Frothy bloat & 183 & 28.8 & 218 & 30.1 \\
Sole ulcers & 32 & 5.03 & 21 & 2.90 \\
Lameness & 48 & 7.50 & 56 & 7.70
\end{tabular}

$\bar{*}$ Not applicable.

Table 3. Average and confidence interval (CI $95 \%$ ) for treatment costs of the main health problems of feedlot cattle for slaughter

\begin{tabular}{|c|c|c|c|c|}
\hline \multirow[t]{2}{*}{ Problems } & \multicolumn{2}{|c|}{2012} & \multicolumn{2}{|c|}{2013} \\
\hline & $\begin{array}{c}\text { Cost } \\
\text { (US\$/animal) }\end{array}$ & $\begin{array}{c}\text { Cost } \\
\text { (in kg LW) }\end{array}$ & $\begin{array}{c}\text { Cost } \\
\text { (US\$/animal) }\end{array}$ & $\begin{array}{c}\text { Cost } \\
\text { (in kg LW) }\end{array}$ \\
\hline Frothy bloat & $31.8 \pm 8,1$ & 20.9 & $22.2 \pm 8.2$ & 13.7 \\
\hline $\mathrm{BRD}$ & $21.3 \pm 1,1$ & 14.0 & $21.7 \pm 1.6$ & 13.4 \\
\hline Ruminal acidosis & $17.3 \pm 2.3$ & 11.4 & $17.8 \pm 3.8$ & 11,0 \\
\hline Sole ulcers & $22.8 \pm 5.6$ & 15.0 & $23.3 \pm 7.0$ & 14.4 \\
\hline Lameness & $15.5 \pm 3.2$ & 10.2 & $15.7 \pm 4.4$ & 9.7 \\
\hline
\end{tabular}

1.52 and 1,62 US\$/kg LW were used for the estimation of cost in kg of LW in 2012 and 2013, respectively. 
complexity and little effect of drugs used to treat frothy bloat generated the greatest treatment expenses. The reason attributed for the lower expenses with treatment of frothy bloat in 2013 was because the veterinarian had adopted a cheaper therapeutic approach (Table 3). In Brazil, the target LW gain is $140 \mathrm{~kg}$ over 100 days in the feedlot. Therefore, it can be estimated that the negative monetary impact for treatment of various problems in feedlot cattle may represent by 7 to $15 \%$ of LW gained over the feeding period (Table 3).

The exaggerated growth (length) of rumen papillae, associated with hyperpigmentation, was the main finding in

Table 4. Main ruminal macroscopic findings from cattle finished for slaughter

\begin{tabular}{lcccc}
\hline & \multicolumn{4}{c}{ Date of slaughter } \\
\cline { 2 - 5 } & $5 / 10 / 2012$ & $8 / 5 / 2013$ \\
\hline Total of examinated rumens & 214 & $\%$ & 171 & $\%$ \\
Exaggerated growth of rumen papillae, & 163 & 76.2 & 121 & 70.8 \\
$\quad$ & & & & \\
$\quad$ Hssociated with hyperpigmentation & 98 & 45.8 & 71 & 41.5 \\
Hyperemic mucosae & 67 & 31.3 & 34 & 19.9 \\
Rumen mucosae with ulcers or ruminitis & 47 & 22.0 & 38 & 22.2 \\
Parakeratosis & 49 & 22.8 & 29 & 17.0
\end{tabular}

Table 5. Average and confidence interval (CI 95\%) for number, length and surface area of rumen papillae of cattle of cattle finished for slaughter

\begin{tabular}{lccc}
\hline & \multicolumn{3}{c}{ Type of rumen papillae } \\
\cline { 2 - 4 } & Parakeratotic & $\begin{array}{c}\text { With excessive } \\
\text { growth }\end{array}$ & $\begin{array}{c}\text { From pasture } \\
\text { diet }\end{array}$ \\
\hline Number (papillae $\left./ \mathrm{cm}^{2}\right)$ & $64.2^{\mathrm{a}} \pm 2.5$ & $39.1^{\mathrm{c}} \pm 3.1$ & $48.7^{\mathrm{b}} \pm 3.8$ \\
Length $(\mathrm{mm})$ & $8.44^{\mathrm{b}} \pm 1.5$ & $13.2^{\mathrm{a}} \pm 2.7$ & $7.72^{\mathrm{b}} \pm 1.8$ \\
Surface area $\left(\mathrm{mm}^{2}\right)$ & $5.46^{\mathrm{c}} \pm 1.1$ & $39.2^{\mathrm{a}} \pm 4.3$ & $18.7^{\mathrm{b}} \pm 2.8$
\end{tabular}

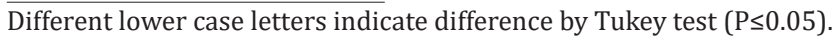

the rumens of finished cattle in 2012 and 2013 (Table 4 and 5 ). The reduction in the surface area of atrophic papillae (parakeratotic) in relation to the papillae of cattle raised exclusively on pastures or those with elongated papillae was 3.4 to 7 times fold, respectively (Table 5).

Cattle fed for slaughter were offered adaptation diets with high amounts of grains and by-products and low roughage. Thus, the $\mathrm{pH}$ of the rumen fluid was higher in the $\operatorname{diet} A_{1}$ than in diets $A_{2}$ and $F$ (Table 6). However, even a pH of 5.68 for $A_{1}$ diet was considered to be near the critical value of 5.60 that is in range for chronic rumen acidosis (Owens et al. 1998). The osmolarity of the rumen fluid followed a rising pattern as the diets had more concentrate in their composition (Table 6).

Blood lactate concentration was always higher in cattle finished for slaughter. The ones raised on pasture, followed by animals of BA and NC farms, were those that had the lowest blood lactate concentrations (Table 6 ). The animals finished for slaughter had feces with the highest osmolarities and the animals raised on pastures had feces with slightly larger osmolarity than the blood, between 280 and $300 \mathrm{mOsm}$ (Table 6). The fecal pH of cattle finished for slaughter was consistently lower than the $\mathrm{pH}$ of feces of the animals fed to be sold as sires or the ones raised on pastures (Table 6). Since the cattle selected to be sires fed at the specialized feedlots, were more valuable and it was not possible to obtain rumen fluid by ruminocentesis to evaluate their ruminal $\mathrm{pH}$ (Table 6).

During the slaughterhouse inspection, cattle without macroscopic findings in the rumen were those which gained more weight and spent less time in the feedlot (Table 7). Costs for additional days on feed resulting from digestive disorders, should also be added to costs for treatments

Table 6. Average and confidence interval (CI 95\%) for physical-chemical parameters measured in cattle in different feedlot systems and pasture diet

\begin{tabular}{lcccccc}
\hline \multirow{1}{*}{ Variable } & \multicolumn{5}{c}{ Type of diet or cattle production system } \\
\cline { 2 - 7 } & $\begin{array}{c}\mathrm{A}_{1} \\
(\mathrm{n}=10)\end{array}$ & $\begin{array}{c}\mathrm{A}_{2} \\
(\mathrm{n}=10)\end{array}$ & $\begin{array}{c}\mathrm{F} \\
(\mathrm{n}=10)\end{array}$ & $\begin{array}{c}\text { Pasture } \\
(\mathrm{n}=10)\end{array}$ & $\begin{array}{c}\text { NC farm } \\
(\mathrm{n}=5)\end{array}$ & $\begin{array}{c}\text { BA farm } \\
(\mathrm{n}=5)\end{array}$ \\
\hline Rumen pH & $5.68^{\mathrm{b}} \pm 0.11$ & $5.19^{\mathrm{d}} \pm 0.20$ & $5.34^{\mathrm{c}} \pm 0.14$ & $6.72^{\mathrm{a}} \pm 0.25$ & $\mathrm{Na}$ & $\mathrm{Na}$ \\
Rumen osmolarity (mOsm/L) & $312^{\mathrm{cd}} \pm 59$ & $358^{\mathrm{b}} \pm 106$ & $402^{\mathrm{a}} \pm 118$ & $289^{\mathrm{d}} \pm 75$ & $\mathrm{Na}$ & $\mathrm{Na}$ \\
Blood lactate (mMol/L) & $6.23^{\mathrm{b} \pm 1.21}$ & $6.10^{\mathrm{b}} \pm 2.03$ & $9.13^{\mathrm{a}} \pm 2.13$ & $4.55^{\mathrm{e}} \pm 1.93$ & $5.02^{\mathrm{c}} \pm 1.19$ & $4.83^{\mathrm{d}} \pm 1.36$ \\
Fecal pH & $6.41^{\mathrm{b}} \pm 0.23$ & $6.33^{\mathrm{bc} \pm 0.26}$ & $6.26^{\mathrm{c}} \pm 0.19$ & $6.71^{\mathrm{a}} \pm 0.29$ & $6.64^{\mathrm{a}} \pm 0.32$ & $6.48^{\mathrm{b} \pm 0.23}$ \\
Fecal osmolarity (mOsm/L) & $381^{\mathrm{b} \pm 46}$ & $399^{\mathrm{a}} \pm 34$ & $388^{\mathrm{b}} \pm 42$ & $311^{\mathrm{e}} \pm 29$ & $325^{\mathrm{de}} \pm 23$ & $342 \mathrm{c} \pm 31$
\end{tabular}

${ }^{*} \mathrm{Na}=$ not analyzed. Different lower case letters indicate difference by Tukey test $(\mathrm{P} \leq 0.05)$.

Table 7. Average and confidence interval (CI 95\%) for main digestive disorders and its effects in days on feed (DOF), average daily gain (ADG), cooled carcass weight (CCW), carcass yield (CY) and daily carcass gain (DCG) of cattle finished for slaughter

\begin{tabular}{cccccccc}
\hline $\begin{array}{c}\text { Type of } \\
\text { animal }\end{array}$ & DOF & $\begin{array}{c}\text { Initial weight } \\
(\mathrm{kg})\end{array}$ & $\begin{array}{c}\text { Final weight } \\
(\mathrm{kg})\end{array}$ & $\begin{array}{c}\text { ADG } \\
(\mathrm{kg})\end{array}$ & $\begin{array}{c}\text { CCW } \\
(\mathrm{kg})\end{array}$ & $\begin{array}{c}\text { CY } \\
(\%)\end{array}$ & $\begin{array}{c}\text { DCG* }^{*} \\
(\mathrm{~kg})\end{array}$ \\
\hline 1 & $95.7 \pm 1.1$ & 343.5 & 461.4 & $1.23 \mathrm{a} \pm 0.25$ & $245.3^{\mathrm{a}}$ & 53.2 & $0.768^{\mathrm{a}}$ \\
2 & $102.4 \pm 20.1$ & 348.7 & 458.2 & $1.07^{\mathrm{b}} \pm 0.26$ & $247.4^{\mathrm{a}}$ & 54.1 & $0.713^{\mathrm{a}}$ \\
3 & $99.3 \pm 9.8$ & 347.8 & 444.3 & $0.972^{\mathrm{b}} \pm 0.21$ & $237.3^{\mathrm{a}}$ & 53.4 & $0.638^{\mathrm{b}}$ \\
4 & $96.2 \pm 12.1$ & 352.0 & 403.2 & $0.532^{\mathrm{c}} \pm 0.22$ & $\mathrm{Na}^{5}$ & $\mathrm{Na}$ & $\mathrm{Na}$
\end{tabular}

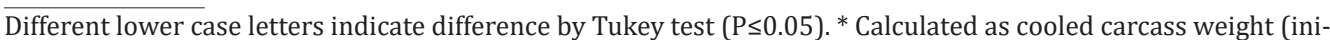
tial weight/2))/days on feed. ${ }^{1}$ With no macroscopic findings in the rumen $(n=86),{ }^{2}$ With parakeratosis ( $\left.n=79\right)$,

${ }^{3}$ Treated for ruminal acidosis $(\mathrm{n}=63),{ }^{4}$ Treated for ruminal acidosis without recovery and subsequent release to pasture $(n=68),{ }^{5}$ Not applicable. 
Table 8. Average and confidence interval (CI 95\%) for feedlot to produce sires

\begin{tabular}{cccc}
\hline & \multicolumn{3}{c}{ NC farm (n=89) } \\
Days on feed & Initial weight $(\mathrm{kg})$ & Final weight $(\mathrm{kg})$ & ADG $(\mathrm{kg})$ \\
166 & $459.9 \pm 37.1$ & $680.8 \pm 51.2$ & $1.33^{\mathrm{b}} \pm 0.25$ \\
& \multicolumn{2}{c}{ BA farm (n $=73)$} \\
Initial weight $(\mathrm{kg})$ & Final weight $(\mathrm{kg})$ & ADG $(\mathrm{kg})$ \\
131 & $466.4 \pm 37.7$ & $625.5 \pm 36.1$ & $1.21^{\mathrm{a}} \pm 0.14$ \\
\hline
\end{tabular}

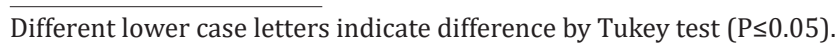

of others health problems, which accounted for an equivalent of 9.7 to $20.9 \mathrm{~kg}$ of live weight (Table 3).

Interestingly, cattle that were affected by digestive disorders had no decrease in carcass yield but spent more time on feed (Table 7). The animals diagnosed with ruminal acidosis and those which had rumens with parakeratosis gained less 0.258 and $0.160 \mathrm{~kg} /$ day, respectively (Table 7). Animals fed to be sold as sires, had ADG similar to cattle finished for slaughter, despite the lower concentrate proportion in their diet but without rumen disorders (Table 8).

\section{DISCUSSION}

During two years of field observation and data collection became evident that the number of cattle diagnosed for any disease and treated during the finishing period in the traditional feedlot systems did not represent the real number of diseased animals. The discrepancy between the number of problems observed by staff and the number of animals examined and treated professionally by a veterinarian suggests that disease diagnosis and treatment are not managed effectively in large scale Brazilian feedlots. Most likely, many cases were not even identified. Chronic understaffing, i.e. four technical staff and one veterinarian on one side and large cattle numbers ( 80.000 or more) on the other side, are a reality in traditional feedlot systems. Unfortunately, this increases the probability that symptoms will be overlooked and treatment of diseases will not be undertaken. For example, professionals stated that during data collection it was a common practice to identify sick animals during a round within a group of 240 cattle and continue the observations in other pens. Since there was only short time to observe all pens, staff chose to contact the veterinarian only for specific cases. Professional medical assistance was sought when they thought an animal would not improve without veterinary interference and disregarded professional help when they considered that the animal had no chances of recovery. This approach is certainly questionable but is believed to describe the reality in large scale Brazilian feedlots.

Another remarkable aspect was that many cattle were found dead overnight or even between visits of health care. The sudden death syndrome (SDS) of feedlot cattle is still underdiagnosed in Brazilian feedlots. Deaths occur suddenly and unexpectedly, i.e. there are no preceding clinical signs (Pierson et al. 1976, Glock \& DeGroot 1998). Under these circumstances necropsy is the only tool available and the lack of clinical signs and epidemiological data do not allow an accurate diagnosis. In several cases of SDS, the macroscopic findings during necropsy were not coherent or meaningful. The etiology of SDS is not yet fully understood. The high prevalence of SDS was probably caused by severe stress due to travel several days under poor conditions (e.g. heat stress, dehydration, dust), high stocking densities in pens and a diet with high percentage of grains and low intake of physically effective fiber. Unfortunately, for this study data of animals that died by SDS were unavailable.

The scientific literature on Brazilian feedlots does not report statistics on prevalence of morbidity and mortality of feedlot cattle which became ill and were treated during their stay in feedlots. Sometimes there are some reports, in non-scientific journals or websites, about morbidity and mortality rates, but it is difficult to obtain reliable conclusions from these sources. Edwards (1996) studied the morbidity of beef cattle in the US based on a survey with feedlot managers, and found that respiratory diseases were diagnosed in 67 to $82 \%$ of the cases and digestive disorders accounted for 3 to $7 \%$ of total diagnoses. These values are quite different from those found in the feedlots evaluated in this study which used data from real observations; e.g. always made in the presence of cattle.

The feedlot for slaughter evaluated in this study purchased cattle that were transported by trucks for several days under adverse conditions such as heat, dehydration and dust, until they reached their final destination. Stress during transport together with increased levels of concentrate in $A_{1}, A_{2}$ and $F$ diets are considered to be the major predisposing factors for the numerous cases of BRD observed in this feedlot (Table 1).

The health problems commonly observed in the feedlot for slaughter have not been diagnosed in those systems which fed animals to be sold as sires. This was most likely because the selling price of an animal of this system is very high, so the nutrition and the prophylactic health management put in place in those types of feedlots is very demanding. It would be disastrous, for example, if a farmer bought a sire with lameness caused by high intake of concentrate during the feeding phase prior of having the bull serving cows in a breeding season. The cow-calf systems in Brazil are predominantly under an extensive management. Thus, an animal with claw injury or sequelae does not have the same mating efficiency than a healthy one.

Snowder et al. (2006) estimated that the average cost on BRD treatment in US feedlots was about US\$13.9 per cattle; much less than the average of US\$ 21.5 found in this study. It appears that there are no publications related to costs with treatment of these problems in beef cattle confined under Brazilian conditions. In the study of Ferreira et al. (2004), costs for the treatment of sole ulcers in free-stall dairy cows was US\$72.6.

The exaggerated papillary growth, associated with hyperpigmentation, may not mean an actual increase in ruminal absorptive capacity, as this finding has also been observed in rumens of animals with ulceration, scars and parakeratosis. Variations in the incidence of these macroscopic changes between years (Table 4) are due to changes in diet composition. In 2012 the animals received only mombaça silage ( $\mathrm{pH}$ 4.7) as roughage and in 2013 they had $11.6 \%$ of this silage and $10.1 \%$ of sugar cane bagasse in the 
DM basis. The latter source of drier roughage most likely stimulated more rumination, improving rumen health by increasing saliva production.

In chronic ruminal acidosis, initially the rumen papillae grow excessively in numbers (Table 5) and then become coalescent to form relatively cohesive blocks. The agglutination of the papillae, associated with their atrophy, is a macroscopic finding that if investigated histologically may reveal parakeratosis. Ruminal parakeratosis negatively affects the absorption of volatile fatty acids (VFAs). The loss in absorptive capacity causes accumulation of VFAs in the rumen fluid, what further aggravates the process of ruminal acidosis. Gaebel et al. (1987) found values from 8 to $9 \mathrm{~mm}^{2}$ and 31 to $35 \mathrm{~mm}^{2}$ for the area of rumen papillae of sheep fed a diet containing exclusively hay and $10 \%$ hay and $90 \%$ concentrate diet, respectively. The largest surface area of rumen papillae in animals ingesting more concentrate (Table 5) was considered to be in response to an increased production of VFAs, especially butyrate, which has trophic effect on ruminal epithelium cells and stimulates the papillary growth.

Ruminal fluid values above $350 \mathrm{mOsm} / \mathrm{L}$ may adversely affect food intake and rumination (Welch, 1982). High ruminal osmolarity also inhibits the action of rumen microorganisms, increase the rate of passage of digesta and, due to higher concentration of intraruminal solutes, cause osmotic diarrhea with considerable loss of water and electrolytes. Ruminants on pasture had ruminal osmolarity ranging from 240 to $265 \mathrm{mOsm} / \mathrm{L}$ that contrasted with 280 to $300 \mathrm{mOsm} / \mathrm{L}$ found in animals receiving high concentrate diets (Garza et al. 1989). Another deleterious effect of the rapid influx of water into the ruminal environment is the detachment of rumen papillae, which creates conditions for VFAs, generated by the fermentation of non-fibrous carbohydrates, what damages the rumen wall causing ruminitis and, as a consequence, rumen microorganisms reach the liver and may cause liver abscesses (Owens et al. 1998).

A result of $9.13 \mathrm{mmol}$ lactate/L blood found in cattle in the traditional feedlot system was potentially dangerous, being a predisposing factor for systemic metabolic acidosis (Glock \& Degroot 1998), and could be the cause of the sudden death cases. During data collection it was observed that several animals were seen separated from the others, but with no changes or signs of any problems and, after a certain time, were found dead by staff members. Unfortunately, no cases where the animal was in extremis were found, so that that blood was collected and lactate could be estimated. Maruta \& Ortolani (2002) induced ruminal acidosis in Jersey and Gir cattle and found 11.7 and $6.8 \mathrm{mmol} / \mathrm{L}$ of lactate, respectively, for the two breeds.

The highest fecal osmolarities found in animals finished for slaughter reflects the highest concentration of feed solutes, which reach the large intestine, probably due to the higher rate of passage of digesta from the rumen to small intestine. These cattle had diarrheic feces with higher osmolarity. The animals fed for sale as sires had two patterns of fecal osmolarity - a higher value in May (a month that they were offered more concentrated (50-65\% DM)) and a lower value in April (at the beginning when they had less concentrate in their diet (20-30\% DM)).
The lowest fecal pH in cattle finished for slaughter is probably due to the higher rate of passage of digesta through the gastrointestinal tract and the larger amount of ingested starch that escaped ruminal digestion and reached the large intestine, where it was then fermented by the microorganisms in this compartment and converted to VFAs, which are the cause of dropin the fecal $\mathrm{pH}$ (Table 6). The starch intake was low in the systems that produce cattle for sale as sires, because the concentrate contained mainly citrus pulp and soybean hulls, which are rich in pectin what is not fermented in the rumen to lactic acid like starch. This type of feedstuffs associated with a higher intake of physically effective fiber resulted in fecal $\mathrm{pH}$ highest for the animals raised as sires (Table 6).

Assuming that an animal with a digestive disorder remained confined for four additional days on feed, and the daily cost of a feedlot was US $\$ 1.68 /$ head (or equivalent to $1.1 \mathrm{~kg} /$ day of $\mathrm{LW}$ ), one can estimate the extra costs ofUS\$ 6.72 per animal finished. Therefore, the costs with extra days on feed should be considered by nutritionists before deciding to use high grain diets; e.g. more than 80 to $85 \%$ of concentrate in the composition. If the diet is balanced to ensure rumen health (suitable ratio of concentrate to physically effective fiber, along with sufficient adaptation time), the animals would be less likely to develop digestive disorders; consequently Brazilian feedlots would have less effective operational costs (Table 7).

When performing the economic viability of cattle finished for slaughter it is also important to take into account that many animals treated for digestive disorders do not respond to therapy and have to be removed from the feedlot and placed back into pasture. Unfortunately, it was not possible to access statistics on this topic; we just had the reports of these cases by the veterinarian. This approach most likely results in a considerable loss of revenue, because beside of cost of treatments, there are other expensive costs during the time spent on feed. These animals are commonly called "railers" (Lardy 2013), which means that an animal is removed before the end of the feeding program and taken back to pasture. Feeding costs since the beginning of the feedlot program until the release of these "railers" to pasture should be considered to calculate the effective operational costs of Brazilian feedlots. In the pasture, these animals recover slowly and almost never return to gain weight properly because the sequelae of chronic ruminal acidosis (rumen scars and loss of ruminal absorptive capacity) negatively affects the nutrient absorption capacity.

Despite the lower concentrate proportion in the diet animals fed to be sold as sires, had ADG similar to cattle finished for slaughter (Table 8). This is due to the fact that to raise cattle as sires, besides a higher genetic merit, a careful nutrition is needed to ensure that no digestive disorders happen and guarantee a long and productive life. Also these cattle are raised and confined on the same ranch until they reach proper weight to be sold as sires. This, along with a lower stocking density, as in head per square meter of the confinement, reduces the negative impacts that cause stress in feedlot animals.

In a review of the impact of health problems on the performance of beef cattle, Smith (1998) estimated daily los- 
ses of 0.14 to $0.33 \mathrm{~kg}$ for animals that were affected by BRD during the finishing phase. Unfortunately, specific data on the negative impacts that digestive disorders may have on average daily gain of cattle finished for slaughter, were not available in the Brazilian literature.

\section{CONCLUSIONS}

Cattle finished for slaughter had considerably more health problems than those in systems that fed sires.

Bovine respiratory disease and digestive disorders (ruminal acidosis and frothy bloat) were the main health problems diagnosed in cattle finished for slaughter.

Treatment costs were high, accounting, on average, from 7 to $15 \%$ of the target live weight to be gained during the finishing period of the traditional system.

The exaggerated growth of rumen papillae and parakeratosis were the main macroscopic findings in rumens of feedlot cattle for slaughter.

The rumen and fecal pH were always lower, and the rumen osmolarity and blood lactate higher in animals finished for slaughter.

The time spent on feed was longer for cattle affected by digestive problems as a result of the lower weight gain.

Results from this study suggest that health problems may not only reduce animal productivity and profitability, but also the welfare of animals.

The systemic understaffing of animal workers and veterinarians in large feedlots in Brazil results in under reporting of diseases, lack of understanding of epidemiological context and disease prevention. A cost benefit study would probably help to further examine scientifically these parameters.

Expected savings of costs and application of higher animal welfare standards would better prepare market oriented feedlots for competitive international trade.

Acknowledgements.- We gratefully acknowledge Dr. Axel Colling (AAHL, CSIRO, Australia) and Professor John Gaughan (SAFS, UQ Australia) for valuable suggestions and reviewing the English version of the manuscript.

\section{REFERENCES}

Anualpec 2014. Custo da pecuária intensiva/semi-intensiva em 25 regiões pecuárias. Anuário da Pecuária Brasileira. Editora FNP, São Paulo, SP, p.145-183.
Dirksen G. 1981. Indigestiones en el Bovino. Schnetztor-Verlag GmbH, Konstanz, p.1-79.

Edwards A.J. 1996. Respiratory diseases of feedlot cattle in the central USA. Bovine Pract. 30:5-7.

Ferreira P.M., Leite R.C., Carvalho A.U., Facury Filho E.J., Souza R.C. \& Ferreira M.G. 2004. Custo e resultados do tratamento de sequelas de laminite bovina: relato de 112 casos em vacas em lactação no sistema free-stall. Arq. Bras. Med. Vet. Zootec. 56:589-594.

Gaebel G., Martens H., Suendermann M. \& Galfi P. 1987. The effect of diet, intraruminal $\mathrm{pH}$ and osmolarity on sodium, chloride and magnesium absorption from the temporarily isolated and washed reticulo-rumen of sheep. Quart. J. Exp. Physiol. 72:501-511.

Garza J.D., Owens F.N. \& Breazile J.E. 1989. Effects of diet on ruminal liquid and on blood serum osmolarityandhematocritin feedlot heifers. Okla. Agricult. Exp. Stn <www.beefextension.com/research_reports/ 1989rr/89_13.pdf> Accessed on March 30, 2016.

Glock R.D. \& Degroot B.D. 1998. Sudden death of feedlot cattle. J. Anim. Sci.76:315-319.

Kleen J.L., Hooijer G.A., Rehage J. \& Noordhuizen J.P. 2004. Rumenocentesis (rumen puncture) a viable instrument in herd health diagnosis. Dtsch. Tierärztl. Wochenschr. 111:458-462.

Lardy G. 2013. Cattleman's guide to terminology feedlot <http:// www.ag.ndsu.edu/publications/landing-pages/livestock/cattlemans-guide-to-feedlot-terminology-as-1161> Accessed on March 30, 2016.

Malafaia P., Barbosa J.D., Tokarnia C.H. \& Oliveira C.M.C. 2011. Distúrbios comportamentais em ruminantes não associados a doenças: origem, significado e importância. Pesq. Vet. Bras. 31:781-790.

Maruta C.A. \& Ortolani E.L. 2002. Susceptibilidade de bovinos das raças Jersey e Gir à acidose láctica ruminal: Acidose metabólica e metabolização do lactato. Ciência Rural 32:61-65.

Nagaraja T.G. \& Lechtenberg K.F. 2007. Acidosis in feedlot cattle. Vet. Clin. Food Anim. 23:333-350.

Owens F.N., Secrist D.S., Hill W.J. \& Gill D.R. 1998. Acidosis in cattle: a review. J. Anim. Sci. 76:275-286.

Pierson R.E., Jensen L.H., Lauerman D.A., Saari P.M., Braddy A.E. \& Chesney M.C. 1976. Sudden death in yearling feedlot cattle. J. Am. Vet. Med. Assoc. 169:527-529.

SAS 2003. Statistics (Release 9.1). Users Guide. SAS Inst. Inc., Cary, NC.

Schneider C.A., Rasband W.S. \& Eliceiri K.W. 2012. NIH Image to ImageJ: 25 years of image analysis. Nature Methods 9:671-675.

Smith R.A. 1998. Impact of disease on feedlot performance: a review. J. Anim. Sci. 6:272-274.

Snowder G.D., VanVleck L.D., Cundiff L.V. \& Benett G.L. 2006. Bovine respiratory disease in feedlot cattle: environmental, genetic, and economic factors. J. Anim. Sci. 84:1999-2008.

Welch J.G. 1982. Rumination, particle size and passage from the rumen. J. Anim. Sci. 54:885-894. 